\title{
КУРГАН УРДЖАР: \\ ИСТОРИЯ ОТКРЫТИЯ И НЕКОТОРЫЕ ИТОГИ ИССЛЕДОВАНИЯ
}

\section{(C) 2019 г. Б.А. Байтанаев}

В статье предлагается предварительное сообщение о неразграбленном кургане Урджар с женским погребением, выявленным в 2013 г. в ходе охранных работ, проводившихся в связи с реконструкцией автомобильной дороги Таскескен-Бахты в Урджарском районе Восточно-Казахстанской области. Памятник уникален сохранившися головным убором неординарного захоронения, который возможно полностью реконструировать. Погребение одиночное, выполнено в каменном ящике. В качестве элементов сопроводительного комплекса присутствуют остатки жертвенной пищи в виде костей животных, керамическая и деревянная посуда, изделие из камня наподобие алтарика. Из украшений сохранилась серьга с каменной подвеской. В лаборатории 14 C датирования была получена калиброванная дата. Курган датируется V-IV вв. до н.э. Материалы памятника анализировались группой специалистов, в том числе палеоантропологами, генетиками, биологами, палинологами. В настоящее время изучение материалов из кургана Урджар продолжается.

Ключевые слова: археология, курган, погребение, культура, кочевники, головной убор

Введение. В 2013 г. сотрудниками Института археологии им А.Х. Маргулана в Урджарском районе Восточно-Казахстанской области проводились аварийные археологические работы в связи с реконструкцией автомобильной дороги Таскескен-Бахты (рис. 1). На 45-м километре автодороги в зоне планируемых дорожно-ремонтных работ находился невысокий курган. До раскопок он представлял собой полуразрушенную, сильно задернованную каменную насыпь, неоднократно подвергавшуюся разрушению при различной хозяйственной деятельности человека, проводимой ранее на данном участке автомобильной дороги. Ввиду этого, очевидно, при строительстве дороги насыпь кургана была сдвинута и смещена севернее от ее оси. Курган разрушался и позже, когда на нем устанавливали деревянный столб линии электропередачи.

Описание курганов. В ходе расчистки насыпи были выявлены два примыкающих друг к другу каменных сооружения в виде сложенных из крупных и мелких камней насыпей (рис. 2). Основной объект представляет собой округлую каменную насыпь диаметром $7 \times 7$ м, высота сохранившейся части - 0,6 м, очевид- 


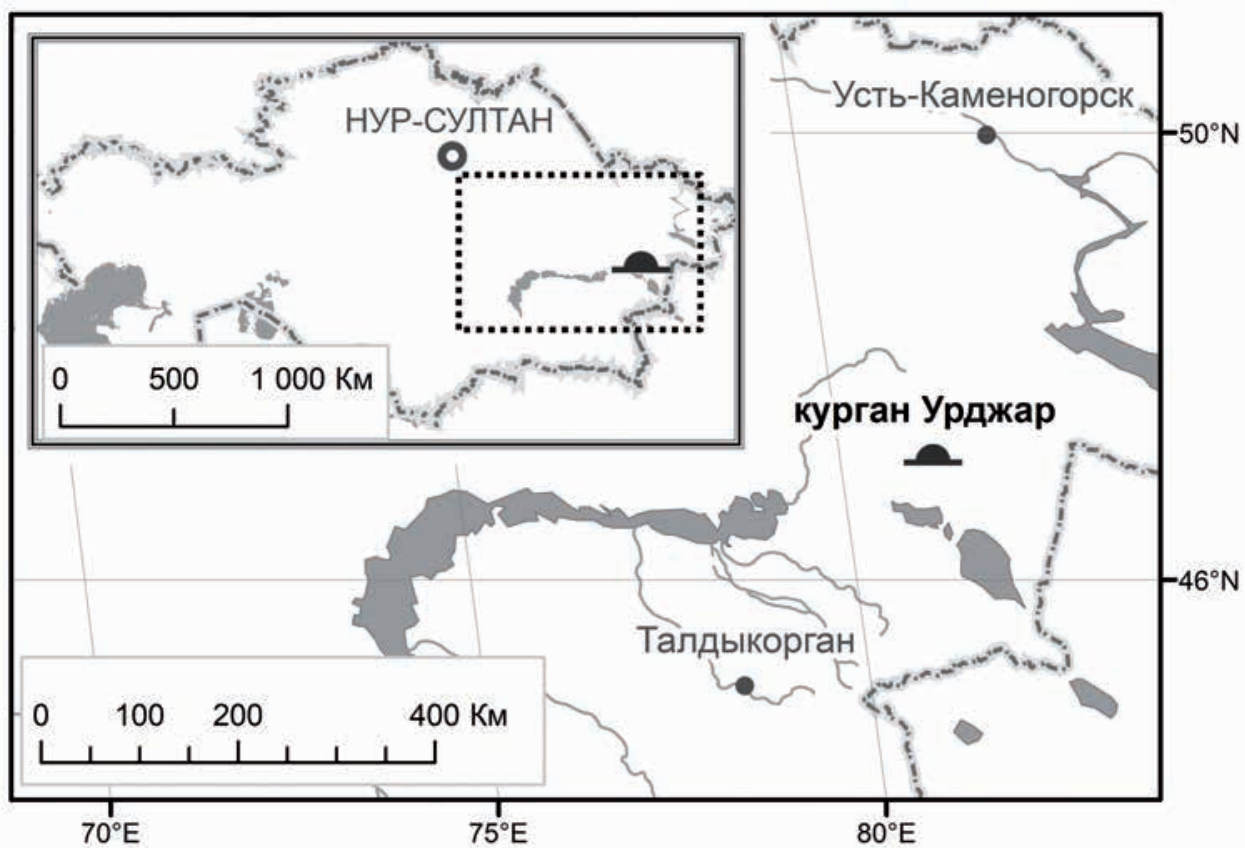

Рис. 1. Курган Урджар на карте Казахстана. Карту подготовил М.А. Антонов

Fig. 1. Kurgan Urzhar on the map of Kazakhstan. The map was prepared by M.A. Antonov

но, первоначальная высота кургана была около 1 м. По периметру насыпи были уложены наиболее крупные камни. В центральной части имеются скопления из более мелких камней. Под насыпью на глубине 0,25 м от уровня материка и 0,85 м от уровня дневной поверхности был расчищен костяк человека. Он находился в скорченном положении на левом боку, ориентирован на запад. Костяк потревожен. Правая рука, часть позвоночника с рёбрами, ключицы, лопатка и череп отсутствовали.

К основному кургану с северозапада примыкала еще одна уплощенная, подквадратной формы, плохо сохранившаяся каменная насыпь, ориентированная своими углами по сторонам света. Ее первоначальный диаметр был около 4 м, высота 0,25-
0,30 м. Основание насыпи выложено крупными камнями, центр - мелкими камнями. В насыпи и под ней ничего не выявлено, что дало основание предполагать о возможности назначения данного сооружения в качестве ритуального или жертвенного места.

В процессе раскопок к западу от стыка обоих курганов было выявлено пятно подпрямоугольной формы размерами 4,25×2,60 м, ориентированное с запада на восток - могильная яма. У западного основания пятна находилось скопление камней, уходящих вниз. При углублении в нем были найдены два овечьих астрагала. Вдоль стен могильной ямы располагались крупные камни, ниже, на глубине 1,25 м, была расчищена каменная кладка подвальной формы. На глубине 1,65 м был выявлен 


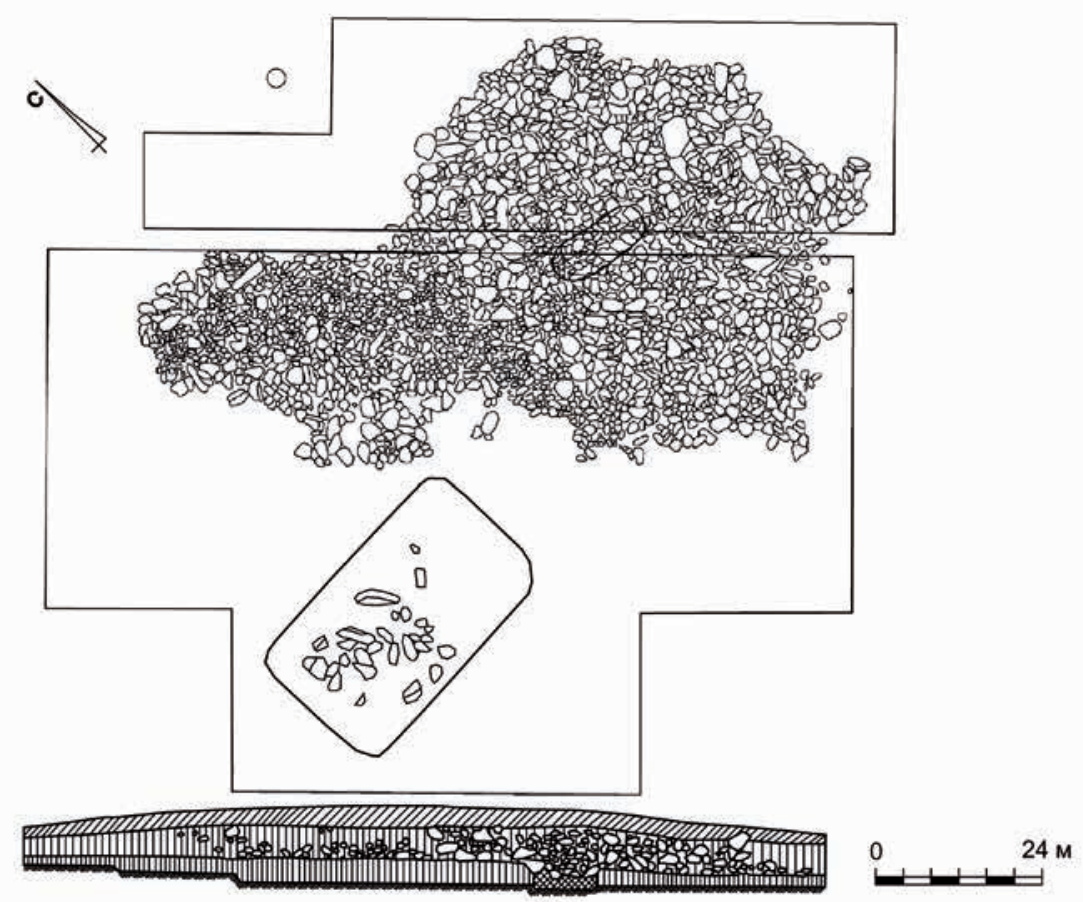

Рис. 2. Урджар. План и разрез кургана

Fig. 2. Urzhar. The plan and section of the mound

каменный ящик с плитами перекрытия (рис. 3). Размеры ямы составили $2,65 \times 4,20$ м, глубина 2,80 м от верхнего края могилы.

Погребальная конструкция была сооружена очень аккуратно, тщательно подобраны и подогнаны плиты (рис. 4). Каменный ящик, состоящий из шести крупных гранитных плит высотой 0,87 м, был вкопан в дно ямы на 15-17 см. Размеры плит: $1,42 \times 1,0$ м; $1,64 \times 0,79$ м; 1,10×0,72 м. Он имел размеры по внутреннему пространству: длину - 2,72 м, ширина в ногах $-0,83$ м, в головах -1 м. Сами плиты ящика были слегка наклонены внутрь, упираясь концами в торцовые стенки ящика. Пространство за ящиком для предотвращения заваливания на внешнюю сторону дополнительно было обложено круп- ными камнями, засыпано материковым грунтом и промазано сверху слоем глины толщиной около 15-20 см. Ящик перекрывался тремя каменными плитами, стыки между которыми были тщательно замазаны глиной. По краям и между стыками плит перекрытия были плотно уложены крупные и мелкие камни, создающие ящику дополнительную герметичность погребения, что обеспечило сохранение захоронения в «вакуумном» пространстве без заполнения ее грунтом.

Остается открытым вопрос о наличии насыпи над захоронением, не выявленной в ходе исследовательских работ.

После демонтажа плит перекрытий, осуществленного при помощи подъемного крана, на дне ящика 
были обнаружены пылевой налет и нетолстый слой тлена, скелет имел широтную ориентацию. Восточная плита погребальной конструкции при изъятии треснула на две части и завалилась вовнутрь ящика, незначительно повредив берцовые кости скелета человека и часть погребального инвентаря. Череп скелета лежал на левой стороне, головой ориентирован на запад, лицом обращен на северовосток. Челюсть фиксировалась в слегка отвисшем виде. Возможно, изначальное положение костяка было иным, он был захоронен на левом боку лицом на северо-восток: ввиду отсутствия заполнения грунта в пространстве могилы после разложения мягких тканей скелет частично завалился на спину, при этом правая рука осталась согнута в локте, кисть ее располагалась в области паха. Левая рука была вытянута и чуть отки- нута в сторону. Левая нога оказалась откинута и слегка согнута в колене, правая зафиксировалась в вытянутом положении. За черепом и на костях скелета зафиксированы следы тлена, являющиеся остатками разложения органики.

У ног скелета, в северовосточном углу ящика обнаружены остатки погребальной пищи, состоящей из задней ноги с тазовой костью (жамбас) и крестца овцы. Нога и тазовая кость овцы лежали среди развала керамического сосуда с ручками котловидной формы. Погребальный инвентарь дополняют деревянная чашка с ручкой, керамический кувшин и деревянное блюдо, где находился крестец овцы. За черепом слева располагался округлый каменный «алтарик». У нижнего основания черепа, у правого уха, обнаружена проволочная серьга с каменной под-

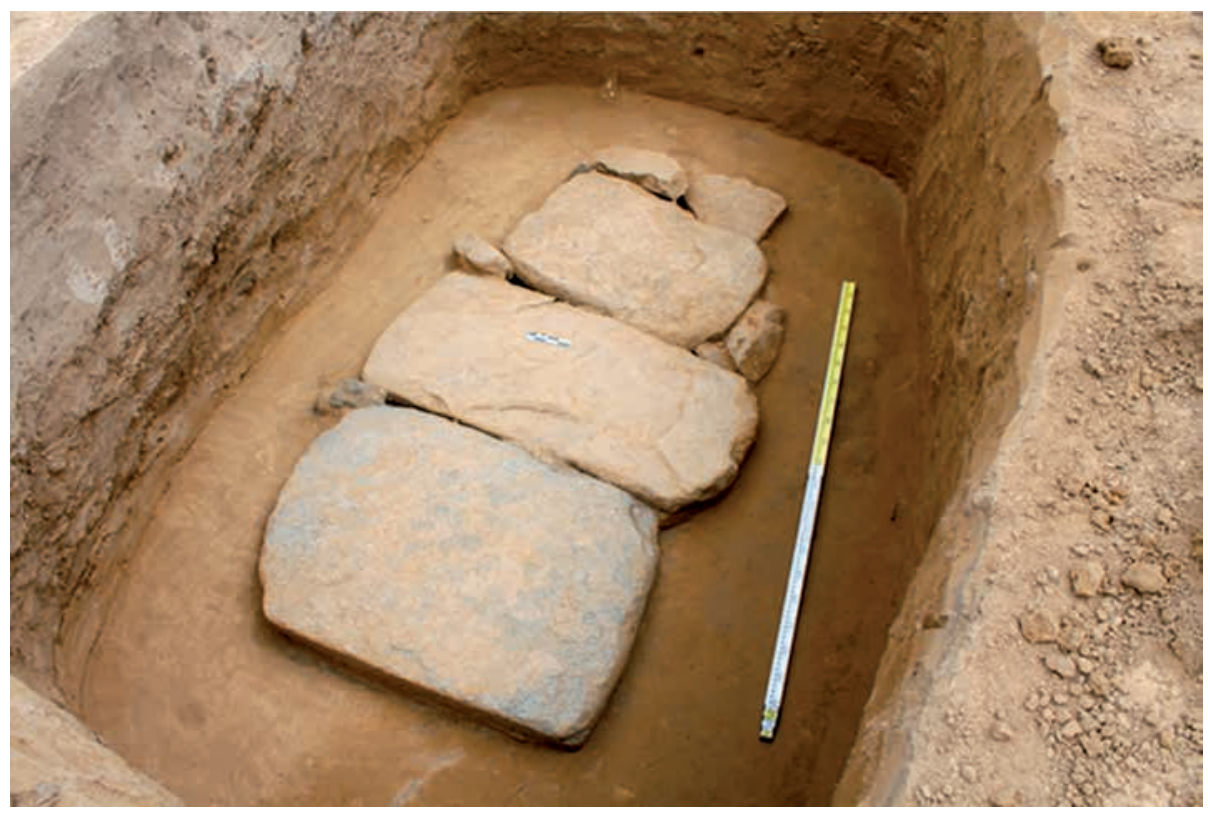

Рис. 3. Урджар. Погребальная конструкция. Плиты перекрытия каменного ящика. Фото из архива Института археологии им. А.Х. Маргулана

Fig. 3. Funerary construction. Stone Box Floor Slabs. Photo from the archives of the A.Kh. Margulan Institute of Archaeology 
веской. За черепом и под ним просматривались предметы из золотой фольги и других элементов головного убора (рис. 5-7).

Методы и методика исследования. Ввиду того, что погребение обнаружено in situ, было решено провести консервацию погребения и доставить в научно-реставрационную лабораторию «Остров Крым» под руководством К. Алтынбекова. Захоронение в соответствии с разработанной методикой было извлечено в виде монолита и помещено в специальный деревянный стеллаж для доставки транспортом в лабораторию. В Алматы сотрудниками лаборатории «Остров Крым» на протяжении ряда лет проводились исследования данной находки на междисциплинарном уровне [Алтынбеков, 2018].

В первую очередь, была произведена комплексная цифровая рент- генография, давшая представление об особенностях одежды захоронения, границах подола, кожаных и иных не сохранившихся, невидимых аппликаций и деталей одежды, по которым были определены основные элементы погребального костюма и головного убора.

Из различных участков погребения был извлечен ряд проб для лабораторных исследований. На основании результатов оптической и электронной микроскопии произведен микрохимический анализ, определены строение и состав тканей, наличие красителей и их цвет (Лабораторные работы проводились отделом научно-технической экспертизы Государственного Эрмитажа. Исследования проводились на оптических микроскопах Биолам-И, Leica M60, Leica DM1000 и электронном микроскопе Hitachi TM 3000. Использова-

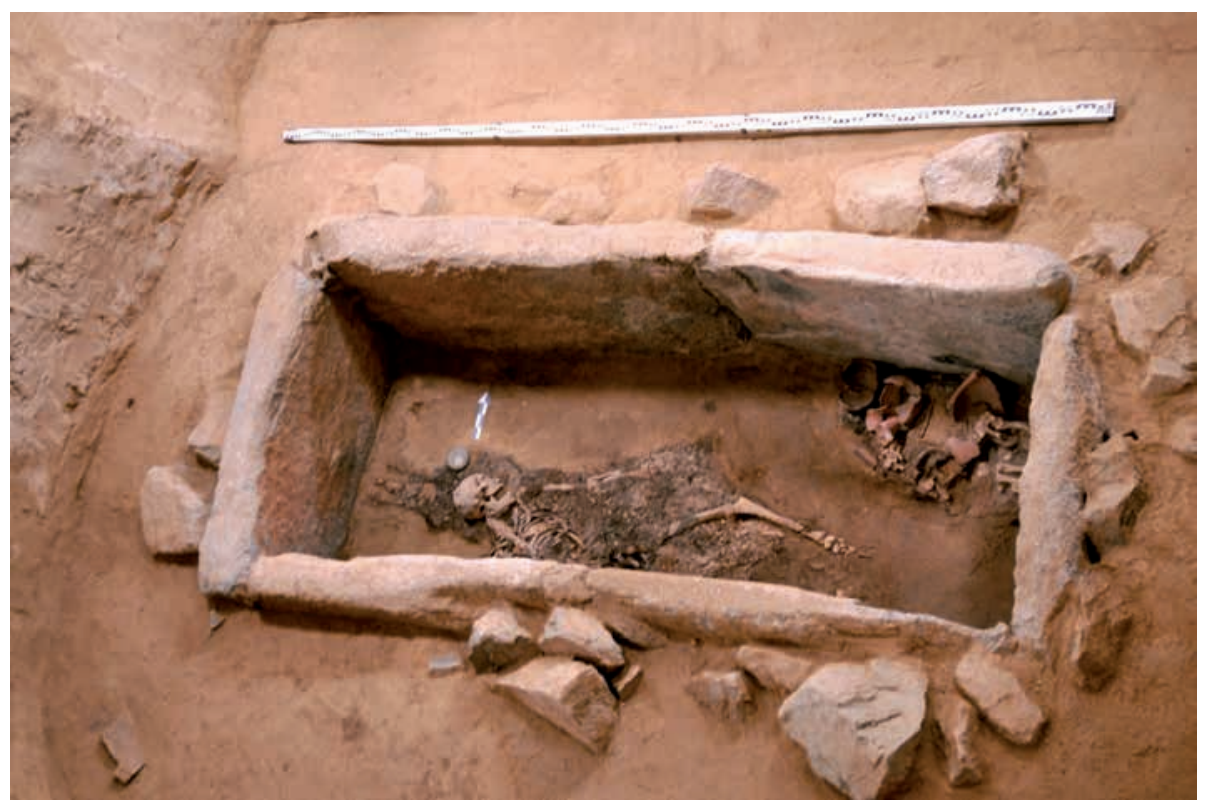

Рис. 4. Урджар. Погребальная конструкиия. Каменный ящик. Фото из архива Института археологии им. А.Х. Маргулана

Fig. 4. Urzhar. Funerary construction. Stone box. Photo from the archives of the A.Kh. Margulan Institute of Archaeology 


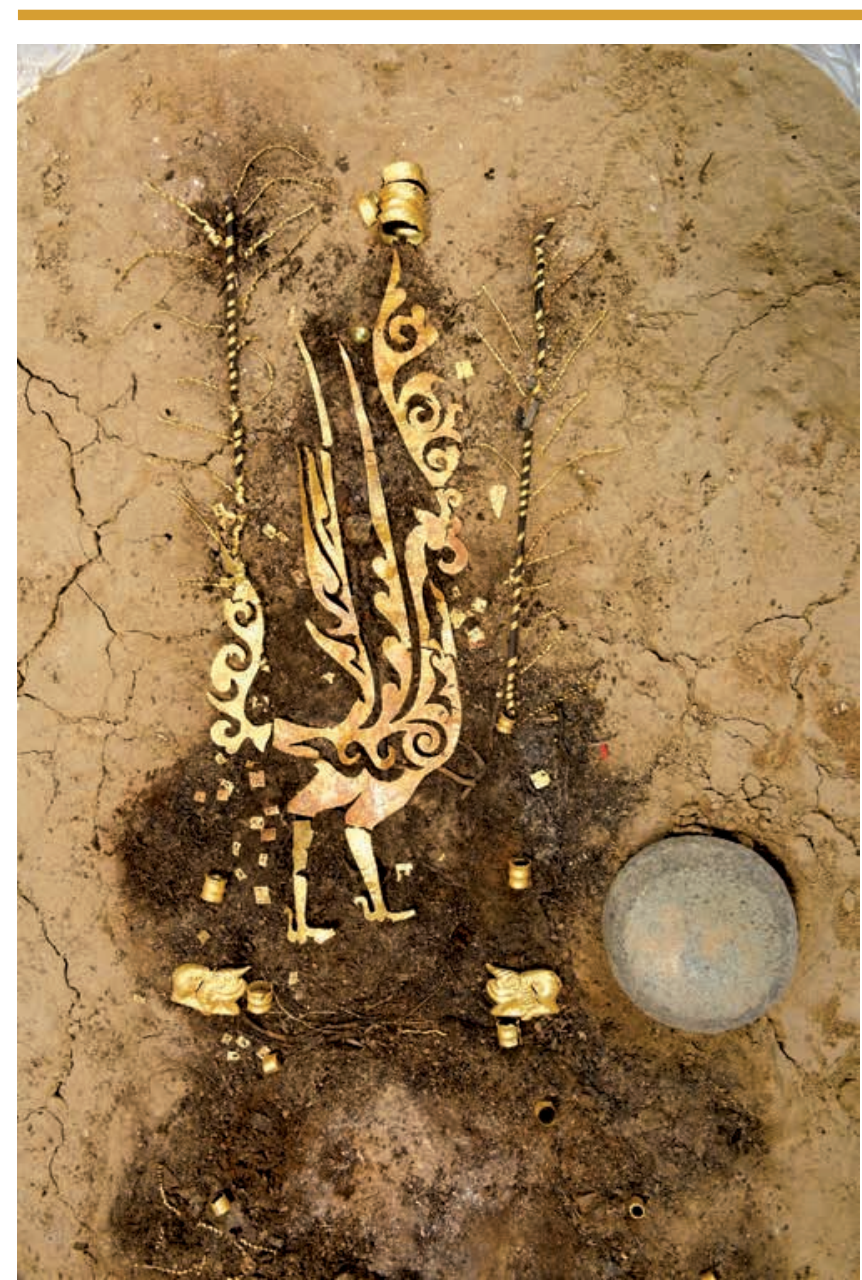

Рис. 5. Урджар. Остатки декора головного убора и каменный «алтарик». Фото О.В. Белялова

Fig. 5. Urzhar. The remnants of the decor headdress and stone «altar». Photo by O. Belyalov пользовались кожаные аппликации черного цвета и тонкая шерстяная ткань, также выкрашенная в красный цвет.

Проба, полученная в районе предполагаемых кос, дала основание полагать, что человек, возможно, был погребен без волос, иными словами, был побрит(?) и имел парик из кос растительных волокон, где в качестве клея использовалась камедь.

Особое внимание было уделено головному убору, зафиксированному до лабораторных работ в изначальном положении, с сохранением всех элементов, деталей. При его реконструкции были учтены все результаты лабораторных анализов. Они показали наличие фрагментов сгнившего дерева, шелка и кожи, что помогло полностью воссоздать погребальный головной лась методика определения строения, состава тканей и красителей). Оказалось, что одежда погребенной имеет плотную структуру. Спектр ткани показал наличие алюминия в глиноземе, который в древнейшие времена в качестве алюминиевой протравы применялся для крашения шерсти мареной и белковых волокон шелка в красный цвет. Несомненно, одежда погребенной изготовлена из тонкой китайской шелковой ткани, выкрашенной в красный цвет. В одежде ис- убор, выполненный в соответствии со скифо-сакскими мифологическими традициями.

По определению реставраторов, головной убор, имея остроконечную конусовидную форму, по сути представлял собой корону, одеваемую на парик. Его верх венчал покрытый золотой фольгой деревянный ребристый цилиндр, основание крепилось к ободку, расположенному горизонтально по височной части головы, верхняя часть которого 
составляла полусфера, обхватывающая макушку головы. Сам ободок с полусферой, очевидно, был изготовлен из тончайшего дерева(?).

По ободку в районе висков были закреплены две крупные бляшки, изготовленные на деревянной основе, покрытые золотой фольгой методом плакировки. На них рельефно изображен лежачий на земле (спящий?) сайгак.

К лобной части ободка в виде «кокарды» когтями прикреплено плоское изображение птицы, имеющей клюв грифона и голову, повернутую влево. Ее венчает гребешок, стилизованный под олений рог. У птицы имеется Г-образный хвост, расположенный вертикально. Основой для этого сюжета, по мнению реставратора,

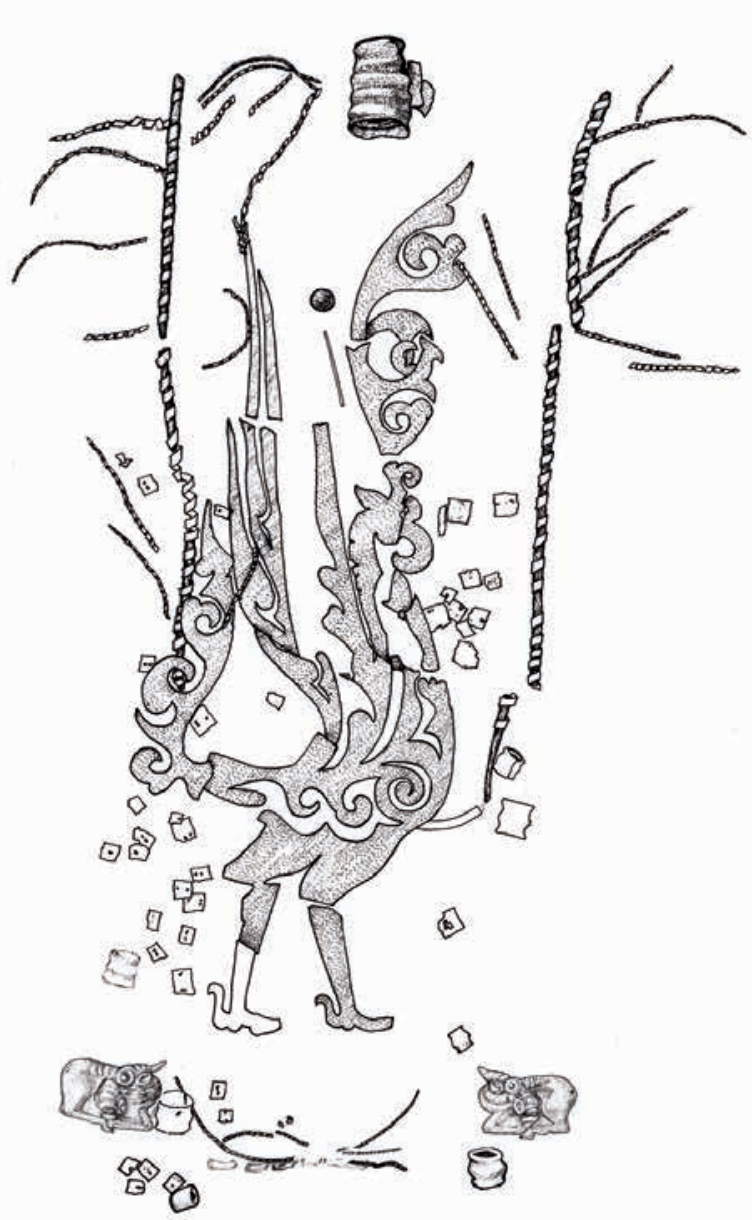

Рис. 6. Урджар. Элементы декора головного убора

Fig. 6. Urzhar. Headwear decor elements послужила плоская форма, представляющая собой «планшет»(?). Возможно, эта форма была изготовлена из вяжущего известкового теста, смешанного с казеином, на что указывают результаты лаборатории. Между вертикально установленной птицей и головным убором размещен металлический стержень, на вершине которого имеется шарик, покрытый золотой фольгой.

Ближе к центру головного убора были установлены два тонких деревянных прута, обернутых в золотую фольгу, по которым, чередуясь,

радиально расходились стебли, сшитые из золотых ниток. Общая конфигурация этих прутьев напоминает стебли папоротника. Перед ними на уровне металлического стержня по ободку вертикально установлены еще два деревянных прута, имитирующих ростки папоротника. Такова в общих чертах реконструкция головного убора урджарского захоронения, предложенная лабораторией «Остров Крым» (рис. 8). Данное описание и реконструкция головного убора в настоящей работе принадле- 


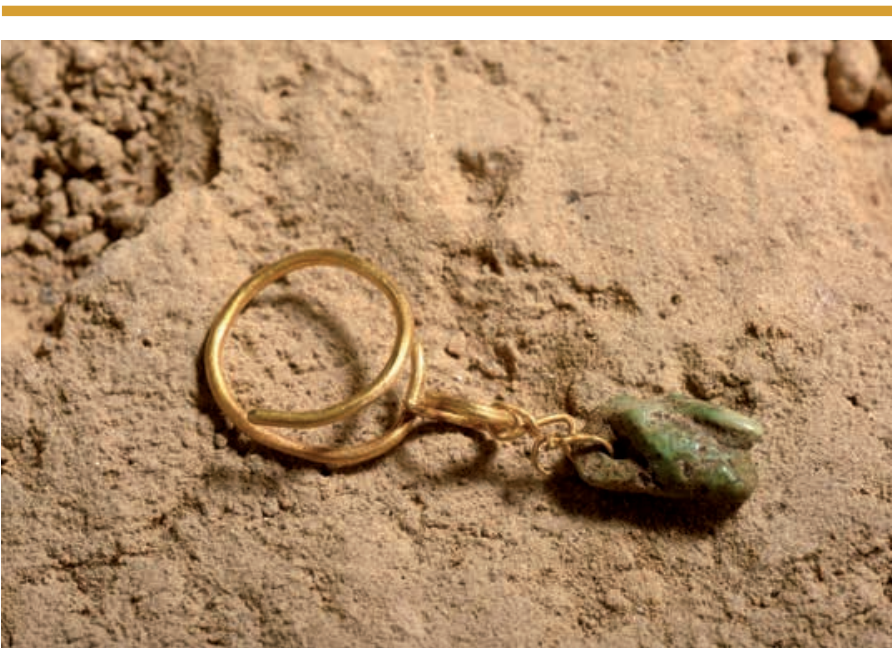

Рис. 7. Урджар. Серьга. Фото О.В. Белялова

Fig. 7. Urzhar. Earring. Photo by O. Belyalov

минералогических наук С.A. Нигматовой) определили наличие папоротника в косе и головном уборе. Найденные почти по всей площади погребения растения семейства осоковых, являющиеся по сути камышом, указали на наличие камышовой циновки, выстланной по дну погребальной камеры.

Повторно исследованные участки левой руки в райо-

жат исключительно К. Алтынбекову. По его мнению, подобный прием в изготовлении головных уборов при наличии парика с использованием деревянной основы имеет аналогии среди племен пазырыкской культуры. Мнение К. Алтынбекова и предложенную им реконструкцию головного убора мы принимаем частично, считая, что аналитический ресурс находки использован не полностью, ввиду этого возможны и другие варианты реконструкции урджарского головного убора.

Интересные результаты были получены с пробы, взятой с левой руки от локтя до ладони. Изначально предполагалось, что там расположены остатки плетения или вышивки. Однако исследования показали наличие в пробе элементов структуры растения, их стеблей в виде пучка, где был опознан специалистами из Петербурга папоротник-орляк.

Дополнительно проведенные в Алматы карпологические и геоботанические исследования (исследования проведены доктором геолого- не предполагаемой «вышивки или мешочка» и ниже к ступне указали на наличие скопления разнотравья, фрагментов растений и их плодов. Среди них: плоды конопли - Cannabis, щавеля - Rume, дриады восьмилепестной - Drýas octopétala, горца птичьего - Polygonum aviculare, триостренника болотного - Triglochin palustris, смолевки обыкновенной Silene, кориандра - Anéthum, зиры Cumīnum cymīnum, Авра́на - Gratiola officinalis, чертополоха - Carduus acantoides, хвои, подорожника и большого количества семян злаков.

Палеоантропологические исследования скелета урджарского захоронения не выявили следов травм и патологических изменений. По черепу определено наличие у захоронения монголоидного облика, связанного своим происхождением с территорией Южной Сибири и Алтая. Подобные краниологические особенности в последнее время часто фиксируются на краниологических материалах из могильников сакского периода с различных регионов Казахстана с 


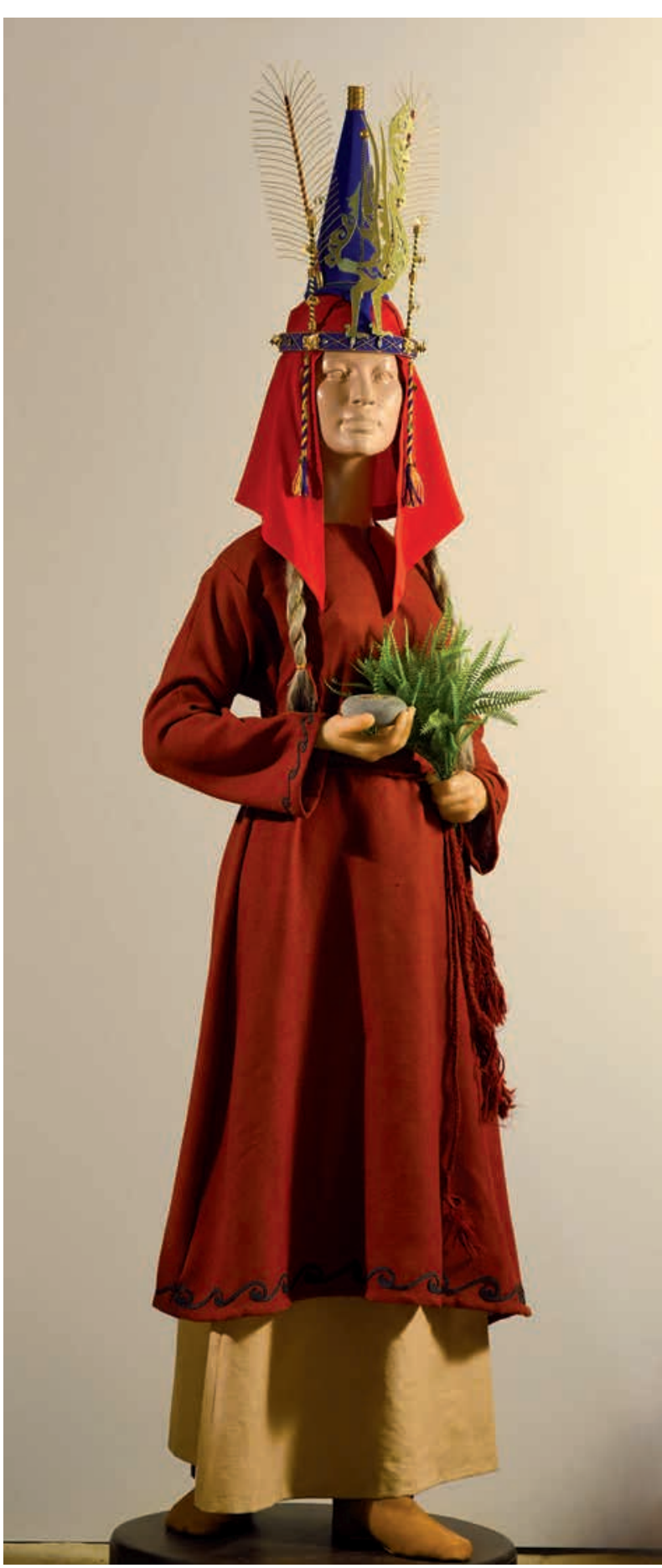

Рис. 8. Урджар. Реконструкиия костюма погребенной женщины. Автор К. Алтынбеков. Фото О.В. Белялова

Fig. 8. Urzhar. Reconstruction of the buried woman's costume. Author K. Altynbekov. Photo by O. Belyalov тенденцией усиления монголоидных особенностей к северу, где ключевую роль в становлении облика ранних кочевников Великой степи всегда играла территория Алтая (подробней см.: Байтанаев, Китов, 2016).

Результаты антропологических исследований в какой-то мере перекликаются с анализом митохондриальной ДНК костных останков, установившем принадлежность к гаплотипу D4, относящемуся к «азиатской ветке», оставившей широкий след в Восточном Алтае, Сибири и Крайнем Севере Евразийского континента и, возможно, среди коренного населения Америки [Джансугурова, Байтанаев и др., 2016].

Р адиоуглеродный анализ (лаборатория, проводившая радиоуглеродный анализ: International Chemical Analysis Inc. шифр: ICA-18W/0815) фрагмента сохранившегося дерева, полученного с погребального инвентаря, подтвердил предполагаемую датировку: $18 \mathrm{~W} / 08152330+/-$ 30 BP

$68.2 \%$ probability 408 to 383 cal BCE

$95.4 \%$ probability 486 to 360 cal BCE $(0.9 \% 271$ to 262 cal BCE)

The lab that measured the date is:

International Chemical Analysis Inc. $10585 \mathrm{NW}$ 53rd ST. Sunrise, FL 33351 
Лаб. шиф: ICA-18W/0815

Материал: дерево (мелкая ветка)

14С возраст л.н. (ВР):

$2330 \pm 30$

Калибр. интервал, лет до н.э. (1б): 408-283

Калибр. интервал, лет до н.э. (2б): 486-360 (0.9\% 271 to 262$)$

$(\mathrm{OxCal}$ v4.3.2; IntCal 13) [Reimer et al., 2013] (рис. 9).

Некалиброванная дата - 2330 +/- 30 ВР. Интервал 2357-2332 cal ВР с вероятностью $68,2 \%$; с вероятностью 94,5\% - 2435-2309 cal BР. Интервал в календарных годах до н.э./н.э. $-408-383$ гг. до н.э. с вероятностью $68,2 \%$ (калиброванное значение), 486-360 гг. до н.э. - с вероятностью $94,5 \%$.

Таким образом, продатированный образец с вероятностью 68\% относится к периоду между 408 и 383 до н.э.

Обсуждение. Некоторые параллели погребальному обряду, в частности, захоронению в ящике под курганной насыпью, можно обнаружить в памятниках пазырыкской культуры. Так, в могильнике Берел, курган 23 был выявлен каменный ящик вдоль южной стенки могильной ямы. Вдоль ее северной стенки располагались кости сопогребенной лошади и керамический сосуд [Самашев, 2011, с. 95-96].

Помимо ящика как погребальной конструкции, в кургане 31 мог. Берел выявлены останки умершего с элементами роскошной одежды. Головной убор погребенного был расшит многочисленными миниатюрными бляшками из золотой фольги и, вероятно, имел конусовидную форму [Самашев, 2011, с. 98-99, рис. 266].

Могильник Тавдушка на Катуни, возможно, демонстрирует больше параллелей кургану Урджар. Так, в кургане 1а был выявлен костяк женщины на правом боку с сильно подогнутыми ногами, головой на ВЮВ, помимо керамического сосуда и хвостовых позвонков барана важным представляется зафиксированное сажистое пятно от высокого женского головного убора, для которого было оставлено свободное пространство более $60 \mathrm{~cm}$, в качестве инвентаря можно отметить бронзовые заколки и восьмерковидную серьгу [Шульга, 2016, с. 257]. Схожие погребения отмечены в курганах 3,5 , но без головного убора. Погребения женщин были совершены в каменных ящиках курганов 4, 8 на правом боку с сильно подогнутыми ногами, головой на ВЮВ и ЮВ. Курганы определяются VI-IV вв. до н.э., культурная принадлежность - пазырыкская культура.

Каменные ящики выявлены в пяти курганах могильника пазырыкской культуры Юстыд [Кубарев, 1991, c. 32-34]. Взрослые представители общества были захоронены только в двух из шести ящиков, традиционно на правом боку, головой на восток.

Погребения в каменных ящиках зафиксированы и в других памятниках пазырыкской культуры Тыткескень-I, VI, Кызык-Телань-I, Кайнду, Кара-Тенеш, Верх. Еланда-2, Бике-I, III, Айрыдаш-III, Дялян, Гурдуба на Катуни. Положение и ориентация погребенных в них типична для пазырыкцев [Кирюшин, Степанова, 2004, с. 12, 125; Кубарев, 1991, c. 32-34].

Нельзя не отметить высокие конусовидные головные уборы в курганах Иссык и Локоть 4а (к. 9, мог. 1 каменской культуры) V-III вв. до н.э. [Акишев, 1978; Шульга, 2003, c. 119-120]. 


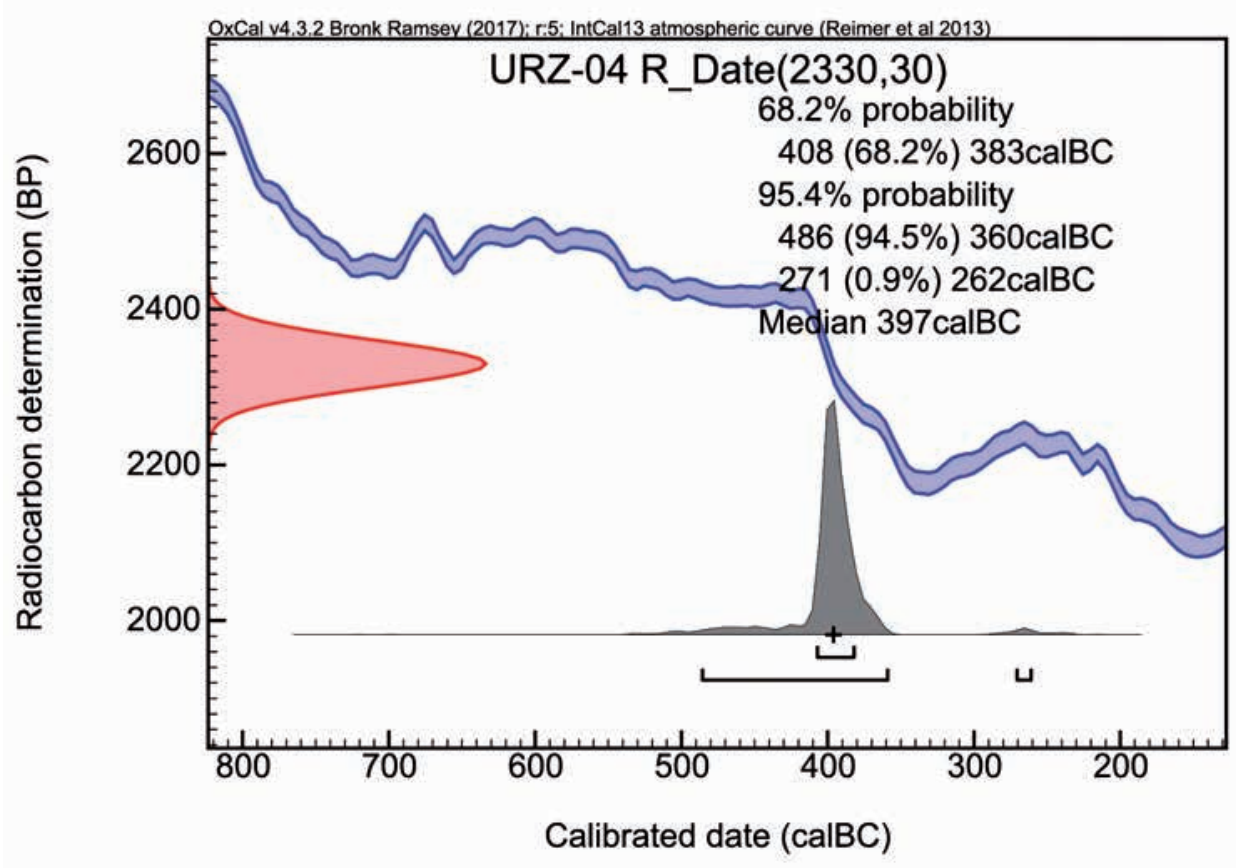

Рис. 9. Результат 14С датирования образиа из кургана Урджар, выполненный в лабopamopuu: International Chemical Analysis Inc. (uифp: ICA-18W/0815)

Fig. 9. Result of $14 C$ dating of a sample from the Urzhar mound, made in the laboratory: International Chemical Analysis Inc. (code: ICA-18W/0815)

Весь комплекс находок и обряд погребения предварительно датировались V-III вв. до н.э., имея широкие аналогии среди памятников Казахстана и сопредельных территорий сако-усуньского времени первой половины I тыс. до н.э.

Заключение. Итоги исследования урджарского захоронения поставили ряд вопросов относительно социальной принадлежности погребенного человека. Обнаруженное погребение нельзя назвать пышным, соответствующим высшему сословию общества той эпохи. Тем не менее, человек с кургана Урджар возможно при жизни имел особый общественный статус. Вероятно, поэтому его могила была устроена в отдалении от родового некрополя без насыпи. Наличие в погребении массы лечебных трав, специально уложенных, наводят на мысль, что погребенный человек мог быть при жизни лекаремжрецом.

К настоящему времени выполнена большая работа по консервации находки, ее реставрации, предложена первая реконструкция костюма «урджарской жрицы» [Алтынбеков, 2018]. Исследования кургана Урджар продолжаются.

Примечание. В статье используются фотографические и иные материалы из полевого отчета по аварийным раскопкам в связи с реконструкцией автомобильной дороги Таскескен-Бахты, хранящегося в архиве Института археологии им. А.Х. Маргулана. Графическое оформление рисунков выполнил Д.С. Джанабаев. Фотосъемка осуществлена О.В. Беляловым. 


\section{ЛИТЕРАТУРА}

1. Акишев К.А. Курган Иссык: искусство саков Казахстана. М.: «Искусство», 1978. 130 с. : ил., цв. ил.

2. Алтынбеков К. Уржарская жрица: история возрождения уникальной находки. Алматы: «Остров Крым», 2018. 94 с.: ил.

3. Байтанаев Б.А., Китов Е.П. Антропологические особенности женского погребения из могильника Урджар // Культурное наследие Евразии (с древности до наших дней): сб. научн. ст. Алматы: Институт археологии им. А.Х. Маргулана, 2016. C. $722-729$.

4. Джансугурова Л.Б., Байтанаев Б.А., Хусаинова Э.М., Нуржибек, Жунусова Г.С., Иксан О.А., Джантаева К.Б., Китов Е.П. Анализ митохондриальной ДНК находки «Урджарская принцесса» // Культурное наследие Евразии (с древности до наших дней): сб. научн. ст. Алматы: Институт археологии им. А.Х. Маргулана, 2016. С. 698-711.

5. Кирюшин Ю.Ф., Степанова Н.Ф. Скифская эпоха Горного Алтая. Ч. ІІІ: Погребальные комплексы скифского времени Средней Катуни. Барнаул: Изд-во Алт. ун-та, 2004. 292 с.: ил.

6. Кубарев В.Д. Курганы Юстыда. Новосибирск: «Наука», 1991. 190 с.

7. Проведение исследовательских работ по теме: «Археологические изыскания на участке реконструкции автомобильной дороги “Таскескен-Бахты (граница КНР)“ 20-60 и моста через реку Каракол в Восточно-Казахстанской области». Научный отчет. Алматы, 2013 // Архив ИА КН МОН РК, ф. 2, оп. 55, д. 3167.

8. Самашев 3. Берел. Berel. Алматы: «Таймас», 2011. 236 с.

9. Шульга П.И. Могильник скифского времени Локоть-4а. Барнаул: Изд-во Алт. ун-та, 2003. 204 с., ил.

10. Шульга П.И. Раскопки могильника Тавдушка на Катуни // Алтай в кругу евразийских древностей. Отв. ред. А.П. Деревянко, В.И. Молодин. Новосибирск: Издво ИАЭТ СО РАН, 2016. С. 253-272.

11. Reimer P.J., Bard E., Bayliss A., et al. INTCAL13 and MARINE13 Radiocarbon Age Calibration Curves 0-50,000 Years Cal BP. Radiocarbon 55 (4): 1869-87. 2013.

\section{Сведения об авторе:}

Байтанаев Бауыржан Абишевич - доктор исторических наук, академик НАН РК, директор, Институт археологии им. А.Х. Маргулана (г. Алматы, Казахстан); baytanaev@mail.ru

\section{ҮРЖАР ҚОРҒАНЫ: АШЫЛУ ТАРИХЫ ЖӘНЕ ЗЕРТТЕУДІН КЕЙБІР ҚОРЫТЫНДЫЛАРЫ}

\section{Б.Ә. Байтанаев}

Мақалада Шығыс Қазақстан облысы Үржар ауданында Таскескен-Бақты автөлік жолындарын қалпына келтіру жұмыстары барысында 2013 ж. қорғау жұмыстары кезінде табылған әйел жерленген тоналмаған Үржар қорғаны туралы хабарлама ұсынылады. Ескерткіш толықтай қалпына келтіруге болатын, бірегей жерленген бас киімнің сақталуымен ерекшеленеді. Жерлеу жеке және тас жәшікте орындалған. Ілеспелі кешеннің бөлшектері ретінде құрбандық астарының қалдықтары жануарлардың сүйектері, керамика мен ағаш ыдыстар, құрбандық шалатын тастан жасалған бұйымдар табылды. Әшекей бұйымдарынан тас салпыншағы 
бар сырға сақталған. 14 С мерзімдеу зертханасынан болжамдалған мерзім алынды. Қорған б.д.д. V-IV ғғ. мерзімделеді. Ескерткіштен алынған материалдар палеоантропологтар, генетиктер, биологтар, палинологтар қатысқан мамандар тобымен сарапталды. Қазіргі таңда Үржар қорғанынан табылған материалдарды зерттеу жалғасын табуда.

Түйін сөздер: археология, қорған, жерлеу, мәдениет, көшпелілер, бас киім

\section{URZHAR MOUND: HISTORY OF DISCOVERY AND SOME RESEARCH RESULTS}

\section{B.A. Baitanayev}

The article proposes a preliminary report on the Urzhar mound that was not pillaged with a female burial identified in 2013 during protection works carried out in connection with reconstruction of Taskesken - Bakhty highway in Urzhar district of East Kazakhstan region. The monument is unique with preserved headdress of extraordinary burial, which can be completely reconstructed. The burial is solitary, performed in a stone box. As elements of accompanying complex, there are remains of sacrificial food in the form of animal bones, ceramic and wooden utensils, and a stone-like item like an altar. From jewelry, an earring with a stone pendant was preserved. In the $14 \mathrm{C}$ dating laboratory, a calibrated date was obtained. The mound dates back to V-IV centuries BC. The materials of the monument were analyzed by a group of specialists, including paleoanthropologists, geneticists, biologists, and palynologists. Currently, the study of the materials from the Urzhar mound continues.

Keywords: archaeology, mound, burial, culture, nomads, headdress

\section{REFERENCES}

1. Akishev, K. A. 1978. Kurgan Issyik: iskusstvo sakov Kazahstana (Kurgan Issyk: the art of the Sakas of Kazakhstan). Moscow: "Iskusstvo" Publ. (in Russian).

2. Altynbekov, K. 2018. Urzharskaya zhritsa: istoriya vozrozhdeniya unikalnoi nahodki (Urjar priestess: the story of the revival of a unique find). Almaty: "Ostrov Krym" Publ. (in Russian).

3. Baitanayev, B. A., Kitov, E. P. 2016. In Baitanayev, B. A. (ed.). Kulturnoe nasledie Evrazii (s drevnosti do nashih dney) (Cultural heritage of Eurasia (from antiquity to the present day)). Almaty: A.Kh. Margulan Institute of Archeology, 722-729 (in Russian).

4. Jansugurova, L. B., Baitanayev, B. A., Khusainova, E. M., Nurjibek, Junusova, G. S., Iksan, O. A., Jantayeva, K. B., Kitov, E. P. 2016. In Baitanayev, B. A. (ed.). Kulturnoe nasledie Evrazii (s drevnosti do nashih dney) (Cultural heritage of Eurasia (from antiquity to the present day)). Almaty: A.Kh. Margulan Institute of Archeology, 698-711 (in Russian).

5. Kiryushin, Yu. F., Stepanova, N. F. 2004. Skifskaya epoha Gornogo Altaya. Ch. III: Pogrebalnyie kompleksyi skifskogo vremeni Sredney Katuni (The Scythian Era of Altay. Part III: The funerary complexes of the Scythian time of the Middle Katun). Barnaul: Altay State University Publ. (in Russian).

6. Kubarev, V. D. 1991. Kurgany Yustyda (Yustyd mounds). Novosibirsk: "Nauka" Publ. (in Russian).

7. Provedenie issledovatelskih rabot po teme: "Arheologicheskie izyiskaniya na uchastke rekonstruktsii avtomobilnoy dorogi "Taskesken-Bahtyi (granitsa KNR) " 20-60 i mosta cherez reku Karakol v Vostochno-Kazahstanskoy oblasti» (Conducting research 
work on the topic: "Archaeological surveys at the site of reconstruction of the" TaskeskenBakhty highway "(border of the People's Republic of China) " 20-60 and the bridge over the Karakol River in the East Kazakhstan region "). In the archive of the A.Kh. Margulan Institute of Archaeology, 2-f. 55-c. 3167-f. (in Russian)

8. Samashev, Z. 2011. Berel. Almaty: "Taymas” Publ. (in Russian).

9. Shulga, P. I. 2003. Mogilnik skifskogo vremeni Lokot-4a (Burial ground of the Scythian time Lokot-4a). Barnaul: Altay State University Publ. (in Russian).

10. Shulga, P. I. 2016. In Derevyanko, A. P., Molodin, V. I. (eds.). Altay v krugu evraziyskih drevnostey (Altay in the circle of Eurasian antiquities). Novosibirsk: Institute of Archeology and Ethnology of the SB RAN, 253-272 (in Russian).

11. Reimer, P. J, Bard, E., Bayliss A, et al. 2013. In Radiocarbon, 55 (4), 1869-1887.

\section{About the Author:}

Baitanayev Bauyrzhan A. Doctor of Historical Sciences, Academician of the National Academy of Sciences of Kazakhstan, Director, A.Kh. Margulan Archeology Institute (Almaty, Kazakhstan); baytanaev@mail.ru

\footnotetext{
Мүдделер қақтығысы туралы ақпаратты ашу. Автор мүдделер қақтығысының жоқтығын мәлімдейді. / Раскрытие информации о конфликте интересов. Автор заявляет об отсутствии конфликта интересов.

/ Disclosure of conflict of interest information. The author claim no conflict of interest.

Мақала туралы ақпарат / Информация о статье / Information about the article.

Редакцияға түсті / Поступила в редакцию / Entered the editorial office: 29.03.2019.

Рецензенттер мақұлдаған / Одобрено рецензентами / Approved by reviewers: 05.04.2019.

Жариялауға қабылданды / Принята к публикации / Accepted for publication: 12.04.2019.
} 